\title{
Geologic reconnaissance of Lautaro Volcano, Chilean Patagonia
}

\section{Akihisa Motoki}

Yuji Orihashi

José A. Naranjo

Daiji Hirata

Pedro Skvarca

Ryo Anma
Departamento de Mineralogia e Petrologia Ígnea, Universidade do Estado do Rio de Janeiro, Rua Sao Francisco Xavier 524, Maracana, Rio de Janeiro, Brasil

amotoki@yahoo.com

Earthquake Research Institute, The University of Tokio, Bunkyo, Tokyo. 113-0032, Japan

oripachi@eri.u-tokio.ac.jp

Servicio Nacional de Geología y Minería, Casilla 10465, Santiago, Chile

jnaranjo@sernageomin.cl

Kanagawa Prefectural Museum of Natural History, Odawara, Kanagawa, 250-0031,Japan hirata@nh.kanagawa-museum.jp

Instituto Antártico Argentino, Cerrito 1248, C1010AAZ, Buenos Aires, Argentina

glacio@dna.gov.ar

University of Tsukuba, Tsukuba, Ibaraki, 305-8571, Japan

anma@arsia.geo.tsukuba.ac.jp

ABSTRACT

Lautaro is the volcano closest to the Chile Triple Junction in the Andean Austral Volcanic Zone. The volcanic edifice of 3,607 $\mathrm{m}$ a.s.l. stands out on the north-western part of the plateau of the South Patagonian Ice Field. The volcano basement is composed of low-grade meta-pelites that are cut by tabular intrusive bodies of hornblende-biotite granite. The volcano is almost completely covered by ice and the study was performed on volcanic detritus present in terminal moraines of the Lautaro Glacier and the tephra on the surface of the O'Higgins Glacier. The terminal moraines of Lautaro Glacier contain fragments of light grey dacite rich in plagioclase and hornblende phenocrysts. Some dacite blocks show prismatic jointing, suggesting an origin of hot emplacement and subsequent rapid cooling, possibly resulted from collapse of a steep lava front. Some samples have glassy groundmass and rhyolite-like flow texture, with presence of mafic inclusions and bread crust bomb texture. The surface of the O'Higgins Glacier is covered by lapilli-size pumice fallout deposit. There are many dirt cones covered by volcanic ash composed of pumice fragments, volcanic glass, quartz, plagioclase, biotite, hornblende, and orthopyroxene. The ash and pumice are similar in chemical composition, both indicating an adakitic signature. At least three layers of fallout deposits have been recognised in parts of the surface of the glacier, which may correspond to the latest known eruptions.

Key words: Adakite, Lautaro volcano, Chilean Patagonia, Austral Volcanic Zone.

\section{RESUMEN}

Reconocimiento geológico del volcán Lautaro, Patagonia chilena. El volcán Lautaro es el más próximo al Punto Triple de la dorsal de Chile en la Zona Volcánica Austral de los Andes. El edificio volcánico de 3.607 m s.n.m. se destaca como el punto más alto en la parte noroeste del plateau del Campo de Hielo Patagónico Sur. El basamento del volcán está compuesto por metapelitas de bajo grado metamórfico que están atravesadas por cuerpos tabulares constituidos por granitos de hornblenda-biotita. El volcán está casi completamente cubierto por hielo y el estudio se 
llevó a cabo en muestras de detrito volcánico presente en las morrenas terminales del Glaciar Lautaro y en tefras que cubren la superficie del Glaciar O'Higgins. Las morrenas terminales del Glaciar Lautaro contienen fragmentos de dacita de color gris claro, rica en fenocristales de plagioclasa y hornblenda. Se observaron algunos bloques de dacita con diaclasamiento prismático, que sugieren un emplazamiento caliente y un subsiguiente enfriamiento rápido, como posible resultado del colapso de un frente abrupto de lava. Algunas muestras de roca tienen matriz vítrea y textura de flujo parecida a riolita, y presencia de inclusiones máficas y textura de bomba de corteza de pan. La superficie del Glaciar O'Higgins está cubierta por ceniza y fragmentos de pómez de tamaño lapilli. Se encontraron numerosos conos cubiertos por ceniza volcánica compuesta de fragmentos de pómez, vidrio volcánico, cuarzo, plagioclasa, biotita, hornblenda y ortopiroxeno. La ceniza y los lapilli son similares en composición química, y ambos con características adakíticas. Se reconocieron por lo menos tres niveles de materiales piroclásticos de caída cerca de la superficie de hielo del glaciar, los que pueden corresponder a las últimas erupciones conocidas.

Palabras claves: Adakita, Volcán Lautaro, Patagonia chilena, Zona Volcánica Austral.

\section{INTRODUCTION}

Lautaro volcano (Volcán Lautaro) is located at $49^{\circ} 01^{\prime} \mathrm{S}, 73^{\circ} 33^{\prime} \mathrm{W}$, in southern Chilean Patagonia (Fig. 1). The volcanic edifice stands out on the northern part of a large ice-cap plateau of the region, called Southern Patagonian Ice Field (Campo de Hielo Patagónico Sur). The summit of the volcano reaches $3,607 \mathrm{~m}$ a.s.l., being more than 1,000 $\mathrm{m}$ higher than the average surface of the ice-cap plateau.

At the nearby Chile Triple Junction (CTJ), ongoing subduction of Chile Ridge takes place (Fig. 1; Barazangi and Isacks, 1976; Cahill and Isacks, 1992). Volcanoes located to the south of the CTJ are characterised by adakitic composition and are grouped in the Andean Austral Volcanic Zone (AVZ; Stern and Kilian, 1996; Stern, 2004). The magmagenesis of adakitic volcanoes is attributed to dehydration melting of oceanic crust on the surface of subducting young and hot slab, the phenomenon called slab melting (Kay, 1978; Defant and Durmmond, 1990). Three northern volcanoes of this volcanic zone, Lautaro, Viedma, and Aguilera, are called northern AVZ and show adakitic signatures with strong crustal overprint (Stern and Killian, 1996).

Lautaro volcano is located at the northern end of the AVZ, being the closest eruptive centre to the CTJ (Fig. 1). Therefore, the eruption style and geochemical characteristics of this volcano may provide important data for interpretation of adakitic volcanism under such tectonic condition. However, the volcanic edifice is located on the ice field and therefore covered by glaciers and snow (Shipton 1960). In addition, the regional weather conditions are very unfavourable for fieldwork, with heavy snowfall and strong wind.

With the help of a helicopter, eruptive materials have been collected from the terminal moraines of

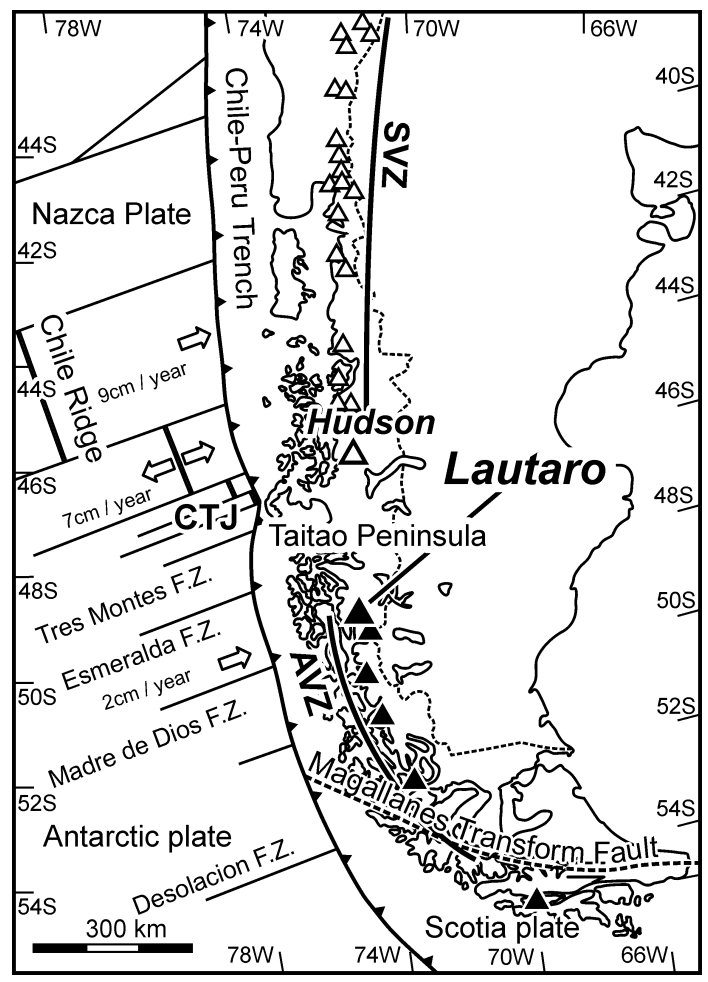

FIG. 1. Locality map of Lautaro volcano, Chilean Patagonia: AVZ, Austral Volcanic Zone; SVZ, South Volcanic Zone; CTJ, Chile Triple Junction. Tectonic elements on the figure are based on Cande and Leslie (1986) and Gorring etal. (1997), and the volcanoes of AVZ on Stern and Kilian (1996). 
the Lautaro Glacier (1:50,000 topographic map 'Portezuelo Santa Bárbara', IGM 5-04-11-0007-00 of the Instituto Geográfico Militar, Chile), on the western side of the South Patagonian Ice Field, and from the surface deposits of the O'Higgins
Glacier, on the north-eastern side (Fig. 2), on February 28th, 2002 (Motoki et al., 2003). Field observations, petrologic and geochemical data from the volcano are herein reported. This work complements that of Orihashi et al. (2004).

\section{TERMINAL MORAINE OFTHE LAUTARO GLACIER}

Lautaro Glacier (Glaciar Lautaro), also called HPS9 glacier (Aniya et al., 2000; Cassasa et al., 2000), has $17 \mathrm{~km}$ long and $600 \mathrm{~m}$ wide in average, and flows along the western flank of the Lautaro volcano edifice (maximum altitude of 3,607 m a.s.I.), with its terminus at a marine fjord (Fig. 2). At the terminal area of the glacier, a young recessional moraine with scarce vegetation cover is present. An observation of aerial photographs reveals that this moraine truncates a glacial valley of Greve Glacier, forming Sor Teresa Lake (Fig. 2). The moraine surface has a rough relief of more than 10 $\mathrm{m}$.

This moraine contains rock blocks, generally less than $1 \mathrm{~m}$ in diameter. They are composed of volcanic rocks, low-grade metamorphosed conglomerates, low-grade meta-pelites, and granites. Many small blocks show rounded shapes, which suggest their origin from the basal parts of the glacier. The largest block observed in this moraine is meta-conglomerate of $5 \mathrm{~m}$ in length, with semi-angular clasts. To the south of this young terminal moraine, another terminal moraine of the Lautaro Glacier is present. It has relatively smooth surface with low vegetation cover, being probably older.

The samples have been collected from both moraines. In total, 35 samples of volcanic rocks were collected, 32 from the former moraine, locality

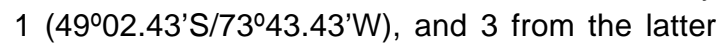
one, locality $2\left(49^{\circ} 04.75^{\prime} \mathrm{S} / 73^{\circ}<44.26^{\prime} \mathrm{W}\right.$; Fig. 2). The most common volcanic rock fragments are light-grey dacites of fresh aspect with abundant plagioclase and hornblende phenocrysts. Some dacite blocks present well-developed prismatic joints, suggesting hot emplacement and following

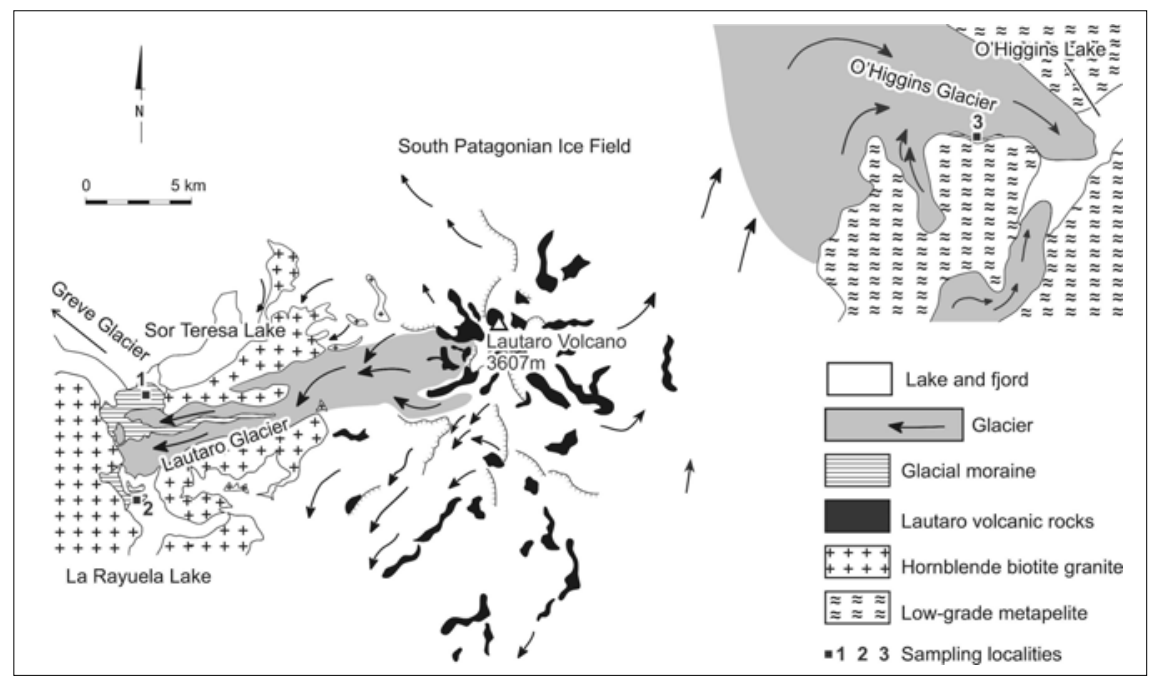

FIG. 2. Geologic map of the northern half of South Patagonian Ice Field, indicating location of the Lautaro and the O'Higgins glaciers and sampling sites, simplified from Orihashi et al. (2004). Bench marks of the sampling sites are: Loc. $1,49^{\circ} 02.43^{\prime} S, 73^{\circ} 43.43^{\prime} \mathrm{W}$;

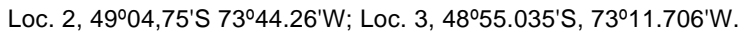


rapid cooling, possibly resulted from collapse of a steep lava front. Several rocks have glassy groundmass and rhyolite-like flow banding. Some samples contain mafic inclusions and show bread crust surfaces. The samples present different degree of alteration. Many wood and tree-trunk fragments were also found within this moraine.

Lateral walls of the fjord expose the basement rocks of the Lautaro volcano. They are mainly formed by low-grade pelitic metamorphic rocks, which are intruded by hornblende-biotite granites. The granite is characterised by abundant rounded enclaves of 10 to $30 \mathrm{~cm}$ in diameter, of granodioritic to dioritic composition. No dacite is exposed in this level. Therefore, the main edifice of the Lautaro volcano could correspond to lava dome clusters partially eroded by glaciers, protruding from the South Patagonian Ice Field (Fig. 3).

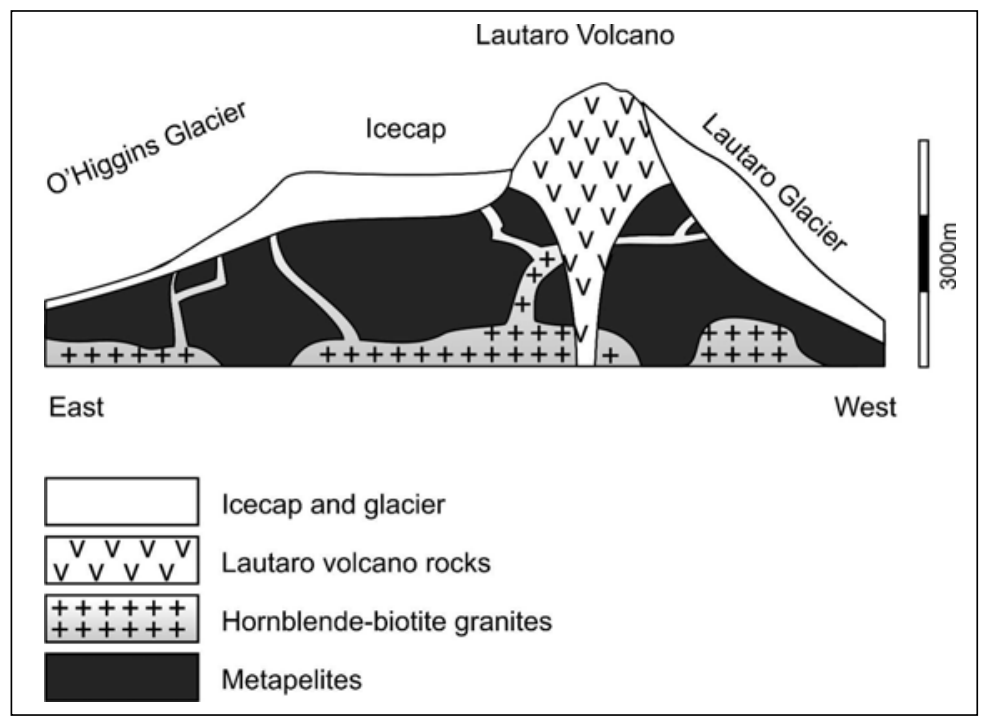

FIG. 3. Schematic geologic cross-section of the northern part of South Patagonian Ice Field plateau, showing the relation between the Lautaro volcanic edifice, the Lautaro Glacier, and the O'Higgins Glacier. The vertical scale is exaggerated approximately four times.

\section{FALLOUTDEPOSITSONTHE SURFACE OFTHEO'HIGGINS GLACIER}

O'Higgins Glacier (Glaciar O'Higgins), 45 km long and $2 \mathrm{~km}$ wide at the distal sector, is located on the north-eastern flank of the South Patagonian Ice Field. The highest part of its accumulation area is 3,706 a.s.l., but the main body forms a flat plateau, more than $20 \mathrm{~km}$ to the north-east of the volcanic edifice, and calves into O'Higgins Lake at $285 \mathrm{~m}$ a.s.l. (Cassasa et al., 2000). In addition, no terminal moraine is currently exposed above the lake water level, but only lateral moraines. The O'Higgins Glacier retreated $14 \mathrm{~km}$ in distance between 1944/45 and 1986 (Aniya et al., 1997).

Lateral walls of this glacier valley expose lowgrade pelitic metamorphic rocks intruded by tabular granitic bodies, typically $10 \mathrm{~m}$ wide, showing the same aspect of the fjord wall of the Lautaro Glacier. The lateral moraine exposed above the glacier surface is approximately $4 \mathrm{~m}$ thick (Fig. 2; locality. 3 ; 48 $\left.{ }^{\circ} 55.035^{\prime} \mathrm{S} / 73^{\circ} 11.706^{\prime} \mathrm{W}\right)$. On the surface of the moraine, there are stripes of linear ridges, several meters high, parallel to the glacier flow. This lateral moraine is composed mainly of angular fragments of meta-pelitic rocks and few blocks of granite. No volcanic rock was found within this deposit.

At the southern margin of the O'Higgins Glacier, a fine layer, $10 \mathrm{~cm}$ thick, of lapilli-sized pumice fallout deposit was observed on the glacier ice. The pumices are usually $2 \mathrm{~cm}$ long, reaching up to 7 $\mathrm{cm}$, slightly elliptic. The ratio of long axis and short one is about 2:3. In total, 122 samples of euhedral pumice were submitted to grain-size analyses. They are well-sorted and approximately $87 \%$ of the samples fall in the range between $6 \mathrm{~mm}$ to $24 \mathrm{~mm}$ in diameter (Fig. 4). 


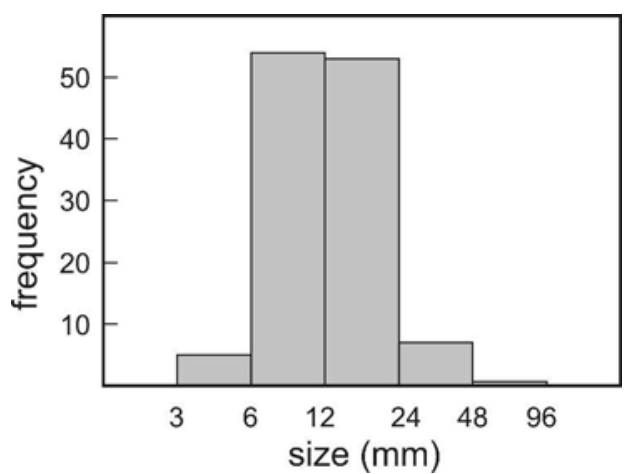

FIG. 4. Grain-size histogram for euhedral pumices collected from the surface of the O'Higgins Glacier.

On the lateral margin of the O'Higgins Glacier, there are many triangular ice ridges lower than $1 \mathrm{~m}$ with their surface covered by an ash-sized fallout deposit, called 'dirt cones'. The ash is supposedly made up of reworked fallout deposits of unknown stratigraphic relationship.

The volcanic ash was sieved using screens of $0.8 \mathrm{~mm}$ and $0.4 \mathrm{~mm}$ and processed by panning in order to concentrate heavy minerals. The ash is characterised by high abundance of mafic minerals. This fact suggests that low-density and/or fine-grained materials were eliminated by wind and/or water flowing on the surface of the glacier.

Binocular microscopic observations of the volcanic ash show that it is mainly constituted by light-grey pumice fragments of different sizes, dark blue volcanic glass, quartz, and plagioclase, mainly finer than $0.8 \mathrm{~mm}$, biotite, generally coarser than $0.8 \mathrm{~mm}$, hornblende and orthopyroxene, finer than $0.4 \mathrm{~mm}$. Many mineral grains are surrounded by pumice on the surface. No clinopyroxene and alkali feldspar were found. The pumice fragments are the most abundant material and are present characteristically in the coarser fractions. They include small idiomorphic mineral grains, such as hornblende and orthopyroxene. The plagioclase is variable in size and small crystals often show fragmented shapes. The hornblende and orthopyroxene crystals are euhedral and concentrated in the fraction finer than $0.4 \mathrm{~mm}$. The orthopyroxene has been identified as hypersthene and is more abundant than hornblende.

\section{PRELIMINARY BULK CHEMICAL ANALYSES OF THE ASH AND THE PUMICE}

Preliminary chemical analyses of the fallout deposits on the O'Higgins Glacier, for three pieces of single pumice, one sample of three small pumices, and one sample of ash, show adakitic signature with small compositional variation (Table 1; Fig. 5).

Orihashi et al. (2004) presented simple geochemical diagrams for the samples collected from the Lautaro Glacier moraine, localities 1 and 2 (Table 2; Fig. 5A). Their chemical composition is of relatively narrow variation, e.g., $\mathrm{SiO}_{2}, 60.5-67.5$ wt\%; $\mathrm{TiO}_{2}, 0.53-0.90$ wt\%; $\mathrm{Al}_{2} \mathrm{O}_{3}, 14.8-16.4$ wt\%; $\mathrm{K}_{2} \mathrm{O}, 0.78-2.19$ wt\%. However, the distribution range is wider than previous data of northern AVZ of Stern and Killian (1996). The variation of MgO content is notable, ranging from 1.88 to $4.07 \mathrm{wt} \%$. The sample with the lowest $\mathrm{SiO}_{2}$ has the highest $\mathrm{MgO}$, showing high-magnesia andesite-like tendency.

On $\mathrm{SiO}_{2}$ versus $\mathrm{K}_{2} \mathrm{O}$ diagram presented in Orihashi et al. (2004), the analysed samples are plotted close to the $\mathrm{SiO}_{2}$ high-end of the distribution range of the Lautaro Glacier's samples. The Lautaro data of Stern and Kilian (1996; horizontally stripped area on Fig. 5A) fall on a small area near the fallout deposits on the O'Higgins Glacier, but have slightly higher $\mathrm{SiO}_{2}$ and $\mathrm{K}_{2} \mathrm{O}$ contents.

Stern and Kilian (1996) discussed in detail adakitic chemical characteristics of AVZ volcanoes, such as high $\mathrm{Al}_{2} \mathrm{O}_{3},>15 \mathrm{wt} \%$, low HREE, $\mathrm{Yb}<1.9 \mathrm{ppm}$, $\mathrm{Y}<18 \mathrm{ppm}$, high Sr, $>400$ ppm, high Sr/Y ratio, $>40$, and positive $\mathrm{Sr}$ and Eu anomalies (Fig. 5B). They attributed high-magnesia andesite of Cook Island with distinctive MORB-like isotopic ratios to 2 to $3 \%$ of slab-partial melting of MORB eclogite and low mantle interaction, less than $10 \%$. For other AVZ volcanoes, they proposed the MORB source magma with mixture of oceanic sediments melt as much as $10 \%$, subsequent very high mantle AFC (combined fractional crystallisation and assimilation with mantle), and high crustal AFC. The mantle and crustal AFC estimated for Burney and Reclus volcanoes are respectively $150 \%$ and 10 to $15 \%$, 
A

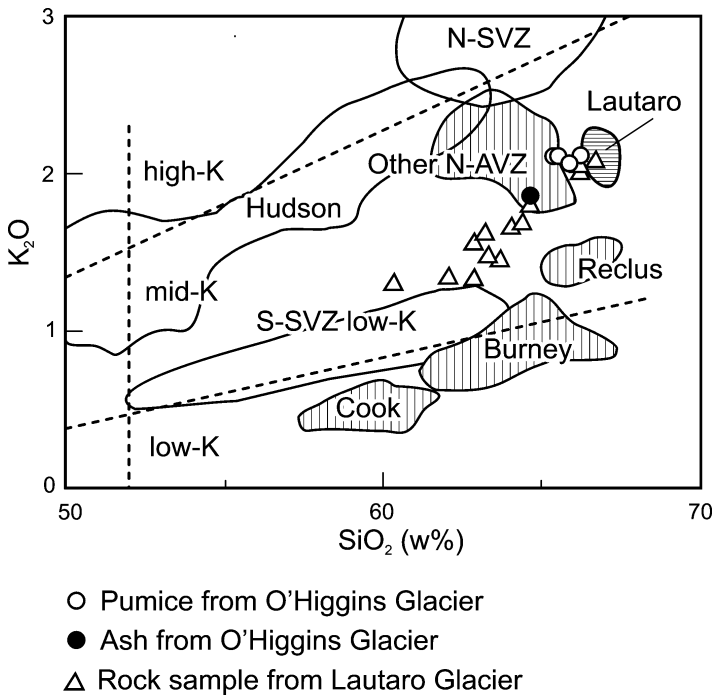

B

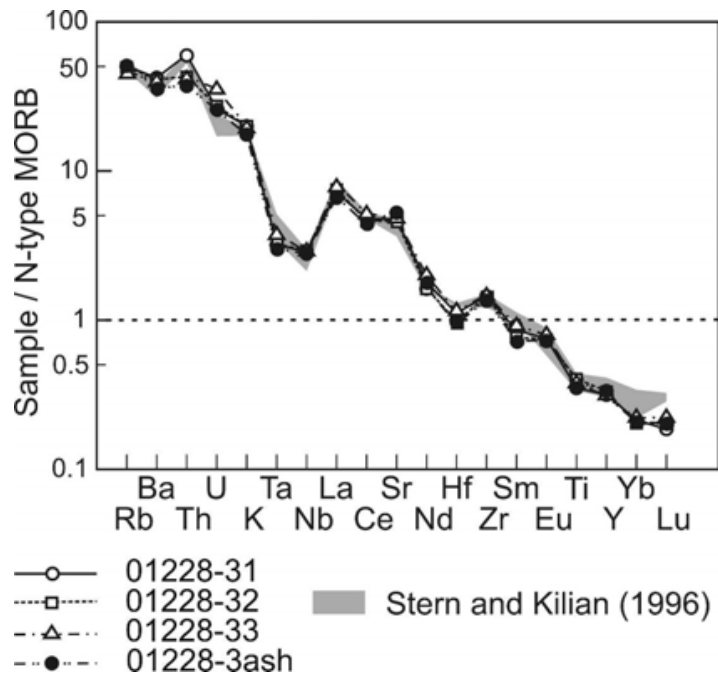

Fig. 5. $\mathrm{SiO}_{2}$ versus $\mathrm{K}_{2} \mathrm{O}(\mathrm{A})$ and $\mathrm{Y}$ versus $\mathrm{Sr} / \mathrm{Y}(\mathrm{B})$ diagrams for Lautaro eruptive materials in comparison with known geochemical data of the AVG and adjacent volcanic zones. N-AVZ, N-SVZ, and S-SVG correspond respectively to northern Austral Volcanic Zone, northern South Volcanic Zone, and southern South Volcanic Zone. Data of the N-AVZ volcanoes, Reclus, and Burney from Stern and Kilian (1996; striped areas; see also Stern, 2004), low-K S-SVZ from López-Escobar et al. (1993), N-SVZ from Futa and Stern (1988), rock samples in Lautaro Glacier moraine from Orihashi et al. (2004). Horizontally striped area shows Lautaro data from Stern and Kilian (1996).

and for northern AVZ volcanoes, $120 \%$ and 20 to $30 \%$. This model justifies general tendency of $\mathrm{MgO}, \mathrm{Sr}$, and ${ }^{143} \mathrm{Nd} /{ }^{144} \mathrm{Nd}$ reduction and $\mathrm{SiO}_{2}, \mathrm{~K},{ }^{87} \mathrm{Sr} /$ ${ }^{86} \mathrm{Sr}$, and $\delta^{18} \mathrm{O}$ elevation from south to north of AVZ volcanoes.

According to Stern and Kilian (1996), the samples of Lautaro, Viedma, and Aguilera volcanoes are dacites with adakite signature and have small geochemical difference. Because of high crustal overprint, eruptive materials of Lautaro volcano can contain partly a significant amount of crustal xenocrysts. However, the geochemical similarity between the ash and pumices collected from the O'Higgins Glacier suggests that these materials are homogeneous and contain limited amount of crustal xenocrysts, if present.

On multi-element spider diagram (Fig. 6), the tephra samples of the O'Higgins Glacier show the same pattern of the Lautaro samples of Stern and Kilian (1996). On the other hand, the chemical variation of the Lautaro rock samples is relatively wide and it may require further detailed geochemical studies.

\section{RECENTVOLCANICERUPTIONSOFTHELAUTAROVOLCANO}

Scarce information is available about historic eruptions of Lautaro volcano because of very low local population density. According to Martinic (1988), at least four historic eruptions are documented: 1876, 1878?, 1933, and 1959-60. Three aerial photographs of the U.S. Air Force Trimetrogon aero-survey taken on 23 January, 1945
(410-R-219; 410-R-206; 556-L-105), show at least three transverse bands of tephra-fall deposits on Chico, Viedma, Occidental, and Greve glaciers originated from Lautaro volcano (Lliboutry, 1999). The satellite images acquired by Landsat 3 RBV (30368-13450-D, Path 248, Row 94; 30368-13453B, Path 248, Row 94) and Landsat MSS (30368- 
TABLE 1. BULK CHEMICAL COMPOSITION OF SINGLE PUMICE PIECES (01228-31, 01228-32, 01228-33), MIXTURE OF THREE PUMICE PIECES (01228-34), AND VOLCANIC ASH (01228-3ASH) COLLECTED FROM THE O'HIGGINS GLACIER, LOCALITY 3 (SEE FIG. 2).

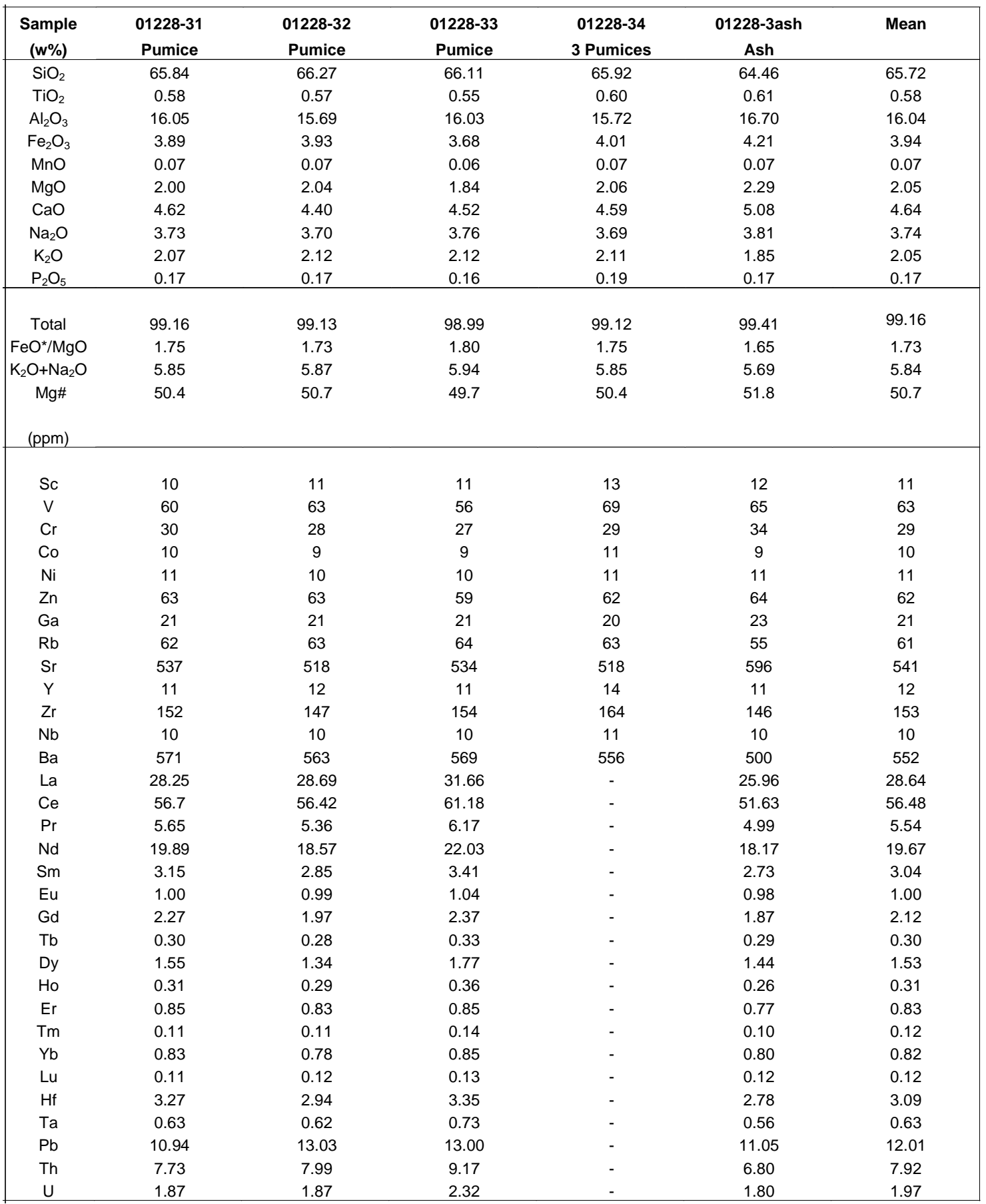

- : Not determined.

REEs, HF, Ta, Th, Pb and U were analysed by LA-ICP-MS and others by XRF at Earthquake Research Institute, University of Tokyo. The detailed analytical procedures are shown in Orihashi and Hirata (2003) and Tani et al. (2002). 
TABLE 2. BULK CHEMICAL COMPOSITION BY MEANS OF XRF FOR THE SAMPLES OF LAUTARO VOLCANO COLLECTED FROM THE LOCALITIES 1 AND 2 (SEE FIG. 2) RELATED TO THE K-AR UNSPIKE DATING OF ORIHASHI ET AL. (2004).

\begin{tabular}{|c|c|c|c|c|c|c|c|c|c|c|}
\hline $\begin{array}{c}\text { Sample } \\
\text { K-Ar age (ka) } \\
\text { (wt\%) }\end{array}$ & $\begin{array}{l}\text { LT1F2 } \\
168 \pm 10\end{array}$ & $\begin{array}{l}\text { LT1H1 } \\
161 \pm 11\end{array}$ & $\begin{array}{l}\text { LT1D1 } \\
114 \pm 7\end{array}$ & $\begin{array}{l}\text { LT1H4 } \\
103 \pm 8\end{array}$ & $\begin{array}{l}\text { LT2B1 } \\
99 \pm 7\end{array}$ & $\begin{array}{c}\text { LT1A2 } \\
97 \pm 7\end{array}$ & $\begin{array}{l}\text { LT1A5 } \\
86 \pm 68^{*}\end{array}$ & $\begin{array}{l}\text { LT1B3 } \\
68 \pm 97^{*}\end{array}$ & $\begin{array}{l}\text { LT2A1 } \\
30 \pm 73^{*}\end{array}$ & Mean \\
\hline $\mathrm{SiO}_{2}$ & 66.76 & 63.58 & 66.6 & 60.55 & 66.52 & 67.37 & 67.41 & 65.68 & 66.91 & 65.71 \\
\hline $\mathrm{TiO}_{2}$ & 0.58 & 0.71 & 0.54 & 0.9 & 0.53 & 0.57 & 0.56 & 0.64 & 0.59 & 0.62 \\
\hline $\mathrm{Al}_{2} \mathrm{O}_{3}$ & 16.1 & 16.6 & 16.55 & 16.83 & 16.69 & 16.15 & 15.9 & 16.38 & 16.03 & 16.36 \\
\hline $\mathrm{Fe}_{2} \mathrm{O}_{3}$ & 3.93 & 4.91 & 3.82 & 5.73 & 3.73 & 3.82 & 3.76 & 4.22 & 3.93 & 4.21 \\
\hline $\mathrm{MnO}$ & 0.07 & 0.08 & 0.06 & 0.09 & 0.06 & 0.06 & 0.06 & 0.07 & 0.07 & 0.07 \\
\hline $\mathrm{MgO}$ & 2.03 & 3.2 & 1.91 & 4.07 & 1.88 & 1.92 & 1.9 & 2.39 & 2.04 & 2.37 \\
\hline $\mathrm{CaO}$ & 4.56 & 5.58 & 4.89 & 6.31 & 4.91 & 4.43 & 4.34 & 4.98 & 4.53 & 4.95 \\
\hline $\mathrm{Na}_{2} \mathrm{O}$ & 3.76 & 3.75 & 3.79 & 3.69 & 3.84 & 3.81 & 3.77 & 3.88 & 3.7 & 3.78 \\
\hline $\mathrm{K}_{2} \mathrm{O}$ & 2.09 & 1.63 & 1.85 & 1.47 & 1.83 & 2.16 & 2.19 & 1.85 & 2.11 & 1.91 \\
\hline $\mathrm{P}_{2} \mathrm{O}_{5}$ & 0.17 & 0.21 & 0.18 & 0.25 & 0.18 & 0.17 & 0.17 & 0.19 & 0.17 & 0.19 \\
\hline Total & 100.06 & 100.25 & 100.2 & 99.87 & 100.16 & 100.47 & 100.05 & 100.28 & 100.09 & 100.16 \\
\hline $\mathrm{FeO} * / \mathrm{MgO}$ & 1.74 & 1.38 & 1.8 & 1.27 & 1.79 & 1.79 & 1.78 & 1.59 & 1.73 & 1.65 \\
\hline $\mathrm{K}_{2} \mathrm{O}+\mathrm{Na}_{2} \mathrm{O}$ & 5.85 & 5.37 & 5.63 & 5.16 & 5.66 & 5.95 & 5.95 & 5.71 & 5.81 & 5.68 \\
\hline $\begin{array}{c}M g \# \\
(\mathrm{ppm})\end{array}$ & 50.6 & 56.4 & 49.8 & 58.4 & 49.9 & 49.9 & 50 & 52.9 & 50.7 & 52.1 \\
\hline $\mathrm{Sc}$ & 11 & 13 & 11 & 15 & 10 & 8 & 12 & 11 & 11 & 11 \\
\hline $\mathrm{V}$ & 59 & 89 & 63 & 111 & 57 & 59 & 57 & 69 & 62 & 70 \\
\hline $\mathrm{Cr}$ & 29 & 61 & 29 & 86 & 28 & 25 & 26 & 41 & 29 & 39 \\
\hline Co & 9 & 15 & 9 & 19 & 8 & 8 & 8 & 11 & 9 & 11 \\
\hline $\mathrm{Ni}$ & 11 & 27 & 9 & 39 & 10 & 10 & 10 & 18 & 11 & 16 \\
\hline $\mathrm{Zn}$ & 66 & 76 & 66 & 86 & 63 & 63 & 64 & 69 & 66 & 69 \\
\hline $\mathrm{Ga}$ & 18 & 19 & 19 & 19 & 19 & 18 & 18 & 17 & 18 & 18 \\
\hline $\mathrm{Rb}$ & 61 & 46 & 55 & 38 & 53 & 63 & 65 & 51 & 62 & 55 \\
\hline $\mathrm{Sr}$ & 534 & 661 & 653 & 687 & 664 & 532 & 517 & 585 & 519 & 595 \\
\hline$Y$ & 12 & 13 & 11 & 13 & 10 & 12 & 12 & 12 & 12 & 12 \\
\hline $\mathrm{Zr}$ & 158 & 154 & 140 & 154 & 141 & 151 & 155 & 150 & 160 & 151 \\
\hline $\mathrm{Nb}$ & 10 & 9 & 8 & 9 & 8 & 10 & 10 & 9 & 10 & 9 \\
\hline $\mathrm{Ba}$ & 563 & 447 & 513 & 401 & 512 & 558 & 564 & 470 & 574 & 511 \\
\hline $\mathrm{Pb}$ & 13 & 14 & 15 & 11 & 14 & 17 & 16 & 12 & 15 & 14 \\
\hline Th & 8 & 8 & 10 & 4 & 11 & 7 & 7 & 7 & 8 & 8 \\
\hline
\end{tabular}

(*) Samples with high air fraction

The XRF analytical method is the same of the samples of Table 1.

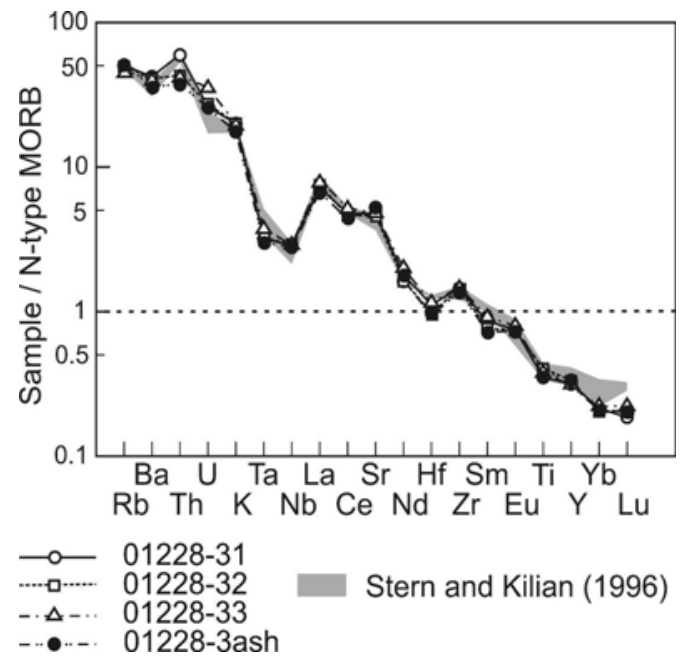

FIG. 6. Multi-element spider diagram for fallout deposits collected from surface of the O'Higgins Glacier. The samples 01228-31, 0122832 , and $01228-33$ are pumice and $01228-3$ ash is volcanic ash. The shaded area presents the Lautaro data from Stern and Kilian (1996). 
13450, Path 248, Row 94) on 8 March 1979, also show tephra from Lautaro volcano covering the western slope of the volcano extending to the south more than $32 \mathrm{~km}$ (Fig. 7). Further to the south, tephra is observed on the upstream areas of Fiordo Falcón and Fiordo Penguin, distant 110 km south from the volcano, and also on Viedma and Upsala glaciers. A small isolated tephra cover is found on the South Patagonian Ice Field, $15 \mathrm{~km}$ to the eastsoutheast of the volcano (Lliboutry, 1999). A fumarole was active on January 29, 1964, confirmed

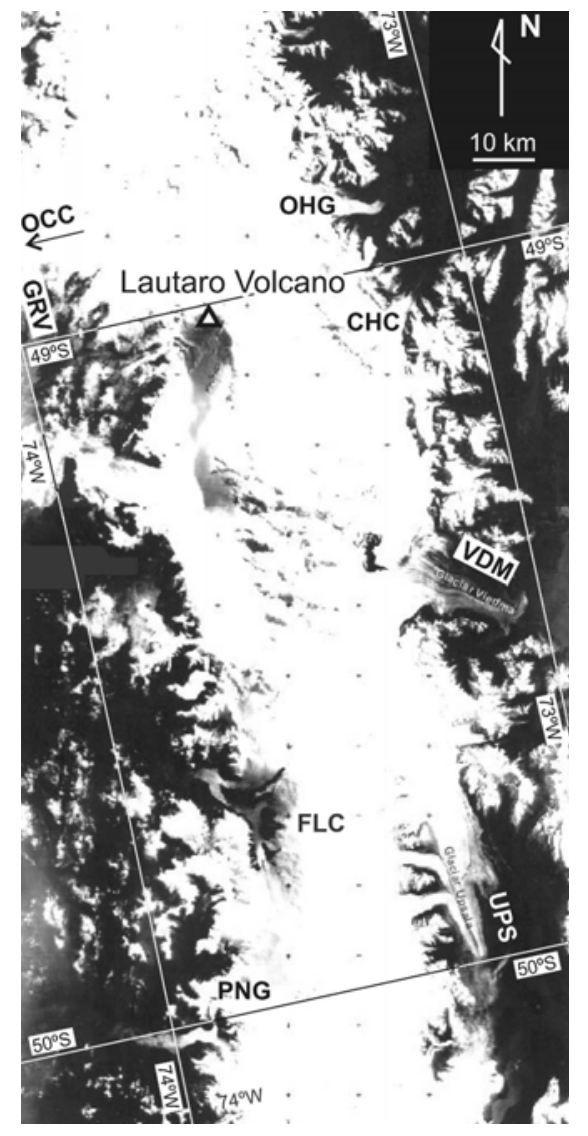

FIG. 7. Composite mosaic image of South Patagonian Ice Field taken by Landsat 3 RBV (30368-13450-D, Path 248, Row 94; 30368-13453-B, Path 248, Row 94) and Landsat MSS (30368-13450, Path 248, Row 94) on 8 March 1979 (Lliboutry 1999), showing tephra from the Lautaro volcano on the plateau, mainly preserved to the south (dark areas). The sites indicated are: Occidental Glacier (OCC) O'Higgins Glacier (OHG); Greve Glacier (GRV); Chico Glacier (CHC); Upsala Glacier (UPS); upstream areas of Fiordo Falcón (FLC) and Fiordo Penguín (PNG). by Skvarca, a co-author of this note, during his first ascent to Lautaro volcano (Fig. 8). These facts indicate that Lautaro is an active volcano, at least with two eruptions in the $\mathrm{XX}$ century.

Hudson volcano, located further north but relatively close to the O'Higgins Glacier, erupted in 1971 and 1991 (Naranjo, 1991; Naranjo et al., 1993; Naranjo and Stern, 1998). However, it cannot be considered as an alternative candidate for the source of the above-mentioned fallout deposits because the phenocrysts of the eruptive materials from Hudson are composed mainly of olivine and/ or clinopyroxene and their bulk chemical compositions show no adakitic signature (Fig. 5), being different from those of the volcanic ash collected from the O'Higgins Glacier. Therefore, the tephra on this glacier should be originated from Lautaro volcano.

On the sidewall of an ice-crevasse of the O'Higgins Glacier at locality 3, at least three young fallout deposit layers close to the glacier surface are visible (Fig. 9), which may correspond to Lautaro's latest known eruptions. The flow velocity of the O'Higgins Glacier is, however, still unknown but could be similar to that of the Perito Moreno Glacier, which is about $620 \mathrm{~m} /$ year (Skvarca and Naruse, 1997). The tephra deposited on the glacier could be entirely carried out in about 60 years, and on the sampling point, locality 3 , in about 30 years. If so, based on a simple calculation the tephra of 1959-60 eruption should be totally swept out by 1990 and the recent tephra layers near the ice surface could be originated from unknown

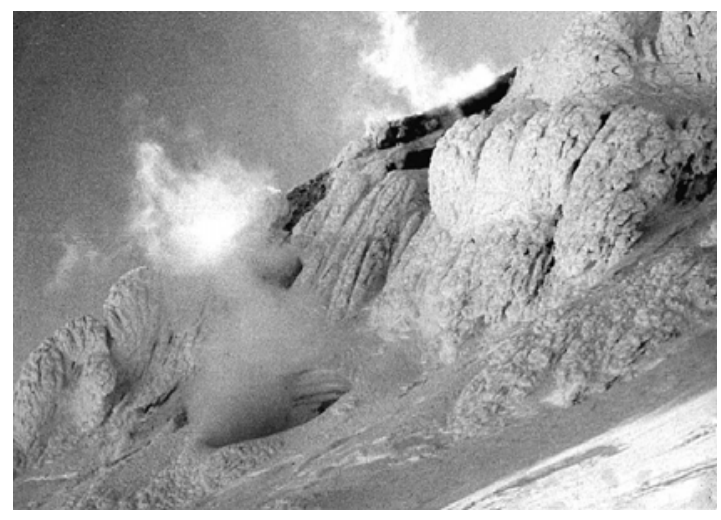

FIG. 8. Fumarole vent located below the summit of the Lautaro volcano and its sulphuric emission. Photograph taken by Pedro Skvarca on January 29, 1964. 


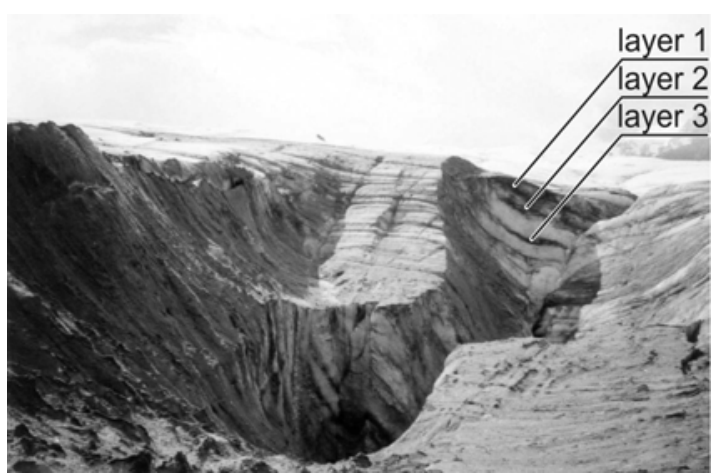

FIG. 9. Ash layers observed on the sidewall of an ice-crevasse of the O'Higgins Glacier at locality 3.

eruptions after 1970. Lliboutry (1999) cited two possible eruptions, in 1972 and 1978, based on oral communications of local farmers. These matters make it possible to infer multiple eruptions of Lautaro volcano after 1970.

The samples collected from the terminal moraines of the Lautaro Glacier give no information about their original stratigraphical position.

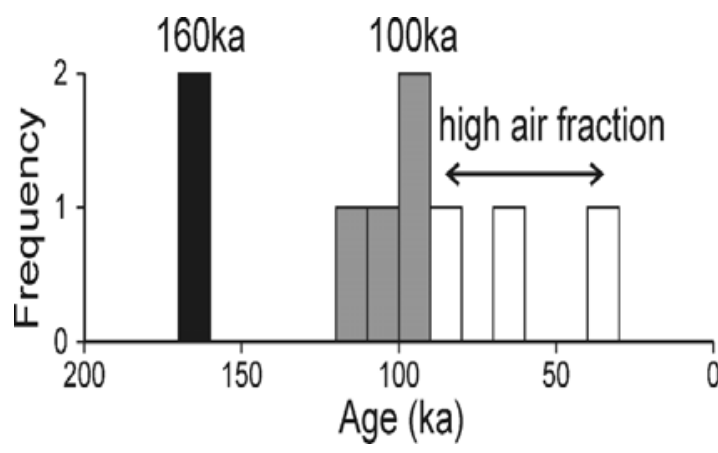

Fig. 10. Age peaks of K-Ar ages of Lautaro rocks from Lautaro Glacier moraine, locality 1 (Orihashi et al., 2004).

However, the K-Ar dating for dacite samples collected from the Lautaro Glacier reveals the existence of different age groups (Orihashi et al., 2004), i.e., two population peaks of the Quaternary, at $100 \mathrm{ka}$ and $160 \mathrm{ka}$, are clearly recognized (Fig. 10). The age peaks for the dacite samples could correspond to lava dome formation events.

\section{ACKNOWLEDGEMENTS}

The authors are grateful to helicopter pilots, lieutenants C. Cofré and J. Carrasco, of the Chile Police Department (Carabineros de Chile) for their courageous and adequate decision during flight operation. The authors are thankful to Professor M. Aniya (Tsukuba University, Japan), for helpful advice in glaciology, to Professor F. Hervé (Universidad de Chile), for local support, and to Professors S. Maruyama (Tokyo Institute of Technology), $\mathrm{H}$. Iwamori (University of Tokyo), and other colleagues of the CHRISTMASSY (Chile Ridge Subduction To Magma Supply System), Project Group for their helpful discussions and support. The present research project is supported by the Science Research Project, process number 13373004, to Ryo Anma, from the Ministry of Education, Culture, Sport, Science and Technology, Japan, entitled 'Chile ridge subduction and temporal special variation of arc volcanic magmatism' (original title in Japanese).

\section{REFERENCES}

Aniya, M.; Dhakal, A.S.; Park, S.; Naruse, R. 2000. Variations of Patagonian Glaciers, South America, Using RADARSAT and Landsat Images. Canadian Journal of Remote Sensing 6 (6): 501-511.

Aniya, M.; Sato, H.; Naruse, R.; Skvarca, P.; Cassasa, G. 1997. Recent Glaciar Variations in the Southern Patagonia Icefield, South America. Arctic and Alpine Research 29 (1): 1-12.
Barazangi, M.; Isacks, B. 1976. Spatial distribution of earthquakes and subduction of the Nazca Plate beneath South America. Geology 4: 686-692.

Cahill, T.; Isacks, B.L. 1992. Seismicity and shape of subducted Nazca Plate. Journal of Geophysical Research 97: 17503-17529.

Cande, S.; Leslie, R.B. 1986. Late Cenozoic tectonic of the 
Southern Chile Trench. Journal of Geophysical Research 91: 471-496.

Cassasa, G.; Rivera, A.; Aniya, M.; Naruse, R. 2000. Características glaciológicas del Campo de Hielo Patagónico Sur. Anales del Instituto Patagonia, Serie Ciencias Naturales (Chile) 28: 5-22.

Defant, M.J.; Durmmond, M.J. 1990. Derivation of some modern arc magmas by melting of young subducted lithosphere. Nature 347: 662-665.

Futa, K.; Stern, C.R. 1988. Sr and Nd isotopic and trace element compositions of Quaternary volcanic centers of the southern Andes. Earth and Planetary Science Letters 88: 253-262.

Gorring, M.L.; Kay, S.M.; Zeitler, P.K. 1997. Neogene Patagonian Plateau lavas: continental magmas associated with ridge collision at the Chile Triple Junction. Tectonics, 16: 1-17.

Kay, R.W. 1978. Aleutian magmatism andesites: Melt from subducted Pacific ocean crust. Journal Volcanology and Geothermal Research, 4: 497-522.

Lliboutry, L. 1999. Glaciers of the Wet Andes. In Satellite Image Atlas of Glaciers of the World, South America. (Williams, R.J.Jr.; Ferringo, J.G.; editors). United States Geological Survey, Professional Papers 1386-I, online version 1.01. http://pubs.usgs.gov/prof/p1386i/ index.html.

López-Escobar, L.; Cembrano, J.; Moreno, H. 1995. Geochemistry and tectonics of the Chilean Southern Andes basaltic Quaternary volcanism (37-46 $\mathrm{S})$. Revista Geológica de Chile 22 (2): 219-234.

Martinic, M. 1988. Actividad volcánica histórica en la Región de Magallanes. Revista Geológica de Chile 15: 181-186.

Motoki, A.; Orihashi, Y.; Naranjo, J.A.; Hirata, D.; Hosono, T.; Cario, F.D.; Anma, R. 2003. Geologic occurrence and recent eruptive materials of the Lautaro Volcano, Chilean Patagonia. Journal of the Geological Society of Japan 109-5: IX-X.

Naranjo, J.A.; Stern, C.R. 1998. Holocene explosive activity of Hudson volcano, southern Andes. Bulletin of Volcanology 59: 291-306.

Naranjo, J.A. 1991. Nueva erupción del volcán Hudson.
Revista Geológica de Chile 18: 183-184.

Naranjo, J.A.; Moreno, H.; Banks, N.G. 1993. La erupción del volcán Hudson en 1991 (465), Región XI, Aisén, Chile. Servicio Nacional de Geología y Minería, Boletín (44): 1-50.

Orihashi, Y.; Hirata, T. 2003. Rapid quantitative analyses of $Y$ and REE abundance of XRF glass bead for selected GSJ reference rock standards using $\mathrm{Nd}$ YAG $266 \mathrm{~nm}$ UV laser ablation ICP-MS. Geochemical Journal 37: 401-412.

Orihashi, Y.; Naranjo, J.A.; Motoki, A.; Sumino, H.; Hirata, D.; Anma, R.; Nagao, K. 2004. The Quaternary volcanic activities of Hudson and Lautaro volcanoes, Chilean Patagonia: new constraints from K-Ar ages. Revista Geológica de Chile 31 (2): 207-224.

Shipton, E. 1960. Volcanic activity of Patagonian Ice Cap. Geographical Journal 126: 389 p.

Skvarca, P.; Naruse R. 1997. Dynamic behavior of Glaciar Perito Moreno, southern Patagonia. Annals of Glaciology 24: 268-271.

Stern, C.R. 2004. Active Andean volcanism: its geologic and tectonic setting. Revista Geológica de Chile $\mathbf{3 1}$ (2): 161-206.

Stern, C.R.; Kilian R. 1996. Role of the subducted slab, mantle wedge and continental crust in the generation of adakite from the Andean Austral Volcanic Zone. Contributions to Mineralogy and Petrology 123: 263281.

Stern, C.R.; Frey, F.A.; Futa, K.; Zartman, R.E.; Peng, Z.; Kyser, T.K. 1990. Trace element and Sr, Nd, Pb and $\mathrm{O}$ isotopic composition of Pliocene and Quaternary alkaline basalts of the Patagonian Plateau lavas of southernmost South America. Contributions to Mineralogy and Petrology 104: 294-308.

Tani, K.; Orihashi, Y.; Nakada, S. 2002. Major and trace component analysis of silicate rocks using fused glass bead by X-ray Fluorescence spectrometer: Evaluation of analytical precision for third, sixth and eleventh dilution fused glass beads. Technical Research Report, ERI, University of Tokyo 8: 26-36 (in Japanese with English Abstract). 